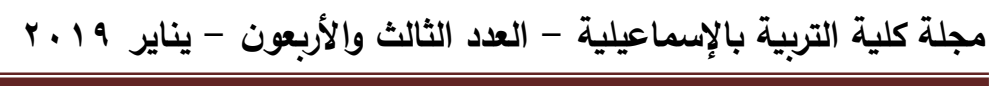

\title{
Authentic Assessment Tasks for Developing Secondary Schoolers' Speaking Skills
}

\author{
By \\ Farid Mohamed Kamal Mohamed Attia* \\ Prof. Mohammed Ismail Abu- Rahmah** \\ Dr. Emad Ahmed Mohamed Albaaly***
}

\section{Introduction}

Speaking English fluently is one of the most important problems which faces the Egyptians' secondary schoolers nowadays. A lot of researches have tried to solve this problem. According to Al Khuli (2000), EITouky (1986), Ghoneim (1992), Hussein (1986), and Seddik (1999) there are several problems teachers and students face in teaching and learning English in Egypt for example learning only the factual information and the students' passive behaviors during the teaching learning process. In my point of view, our educational system is in need of comprehensive or a radical reform that can activate it to respond positively and properly to the requirements of the development process in our country. Complaints of the ineffectiveness of this system, in terms of competent graduates in general, and English language graduates, in particular, can be heard everywhere: in schools, in universities and in the fields where the graduates can be employed. Egyptian learners of English face problems, but the majority of these problems are related to pronunciation. Wahba (1998:36) summarizes these problems:

"...Egyptian students face certain problems related to pronunciation. Some of these problems are related to stress, others are related to intonation. However, most of these problems can be

\footnotetext{
* Research derived from a Master's thesis under supervision of:

**Prof. Mohamed Ismail Abu- Rahmah -Professor of Curriculum \& Instruction (TEFL), Former Vice Dean for Students' Affairs Ismailia Faculty of Education, Suez Canal University

***Dr. Emad Ahmed M. Albaaly - Lecturer of Curriculum\& Instruction (TEFL), Ismailia Faculty of Education, Suez Canal University*

* Farid Mohamed Kamal Mohamed Attia - Expert teacher of English at Fakous Secondary School for Boys since1989 till now.
} 
attributed to the differences in pronunciation between English and Arabic."

Speaking is one of the four language skills (listening, speaking, reading and writing) the means through which learners can communicate with others to achieve certain goals or to express their opinions, intentions, hopes and viewpoints. In addition, people who know a language are referred to as 'speakers' of that language. Furthermore, in almost any setting, speaking is the most frequently used language skill. As Rivers (1981:77) argues, speaking is used twice as much as reading and writing in our communication.

The acquisition of fluent speech habits is relegated to the status of a pleasant luxury; foreign language learners will no longer consider it an essential goal of their course. (Hamzah and Sinnasamy (2009: 186). Foreign language teachers themselves must be such good models that they have the capacity to demonstrate the speaking skill as accurately as possible just like the native speakers of the foreign language.

\section{Context of the problem}

Based on the researcher's experience as a teacher of English at Fakous Military Secondary School for Boys, it was noticed that some students have difficulties in learning speaking skills. These problems lead to the weakness of the students` language performance. These difficulties might be a result of the ineffective methods of teaching speaking that the teachers use at schools which consequently affect the students` learning

In light of the pilot study conducted by the researcher, secondary schoolers had difficulties in learning speaking. In spite of the importance of speaking skills for language competence, the secondary schoolers' achievement in these aspects was low so their performance of language skills was negatively influenced.

Therefore, the current study is attempting to measure the effectiveness of using some authentic assessment tasks on developing speaking skills learning of EFL secondary schoolers.

\section{Questions of the study}

The current study attempted to answer the following main question: "What is the effect of using some authentic assessment tasks on developing speaking skills of EFL secondary schoolers ?" This question could be divided into the following sub questions: 1. What are the speaking skills required for secondary schoolers? 


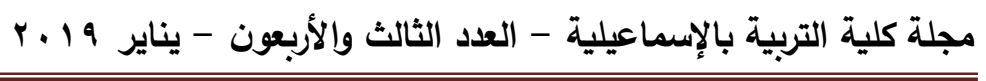

2. What are the features of some authentic assessment based tasks that may enhance those skills?

3. How far are those tasks effective in developing those speaking skills?

Hypotheses of the study:

1. There is a statistically significant difference at 0.01 level between the mean score of the experimental and control groups in the speaking posttest in favour of the experimental group.

2. There is a statistically significant difference at 0.01 level between the mean score of the pre and post speaking test of the experimental group in favour of the posttest.

3. There is a statistically significant difference at 0.01 level between the mean scores of the pre and post speaking test of the experimental group in favor of the posttest of fluency.

4. There is a statistically significant difference at 0.01 level between the mean scores of the pre and post speaking test of the experimental group in favor of the posttest of pronunciation.

5. There is a statistically significant difference at 0.01 level between the mean scores of the pre and post speaking test of the experimental group in favor of the posttest of Coherence and Cohesion.

6. There is a statistically significant difference at 0.01 level between the mean scores of the pre and post speaking test of the experimental group in favor of the posttest of accuracy.

7. There is a statistically significant difference at 0.01 level between the mean scores of the pre and post speaking test of the experimental group in favor of the posttest as a whole.

8. Teaching by using the authentic assessment approach, as a whole, is characterized by a high effect degree on developing English speaking skills.

\section{Method}

The purpose of this study was to investigate the effectiveness of using some authentic assessment tasks on developing secondary schoolers' speaking skills. This chapter tackles the experimental part of the study. It provides a description of the research design, participants, instruments and experimentation. 
Research design and participants:

The experiment was carried out at Fakous military Secondary School for first year boys in Fakous Sharkia through the first term of the school year 2016-2017. The research design in this study is the two group pretest \& posttest design. Two classes were chosen. One group was assigned as the experimental group, while the second group was assigned as the control one. Each group consisted of thirty male students. The experimental group was trained on the use of some authentic assessment tasks for developing secondary schoolers'speaking skills. While the control group was taught in the regular way.

There were two reasons behind choosing such a sample. Firstly , the course of the first year secondary stage includes speaking lessons which can be well dealt using the strategy of authentic assessment tasks. Secondly, the mental abilities of the first secondary year students were high enough to practise this strategy`s activities and skills.

Before the treatment, the researcher had to establish some sort of encouragement and social relationship with the students. The researcher encouraged the participants to use such a useful and modern strategy (authentic assessment tasks). The researcher held an orientation session beginning with showing the participants how they could benefit from the strategy throughout the academic year as well as their daily life afterwards.

\section{Instruments}

The researcher designed four instruments as follows:

1.alist of speaking skills appropriate to the students` level,

2.a speaking pre/post test,

3.assessment checklist and

4.the suggested authentic assessment tasks.

A list of speaking skills appropriate to the students' level:

The researcher prepared a list of speaking skills. The aim of the list was to identify the speaking skills appropriate to first secondary students' level to be taught and assessed using the suggested authentic assessment tasks. Procedurally, the list was developed to find an answer to the first research question "What are the speaking skills required for secondary schoolers?" 
مجلة كلية التربية بالإسماعيلية - العدد الثالث والأربعون - يناير ب ب ب

The speaking test:

The purpose of the speaking test was to assess the students' understanding and ability to use the authentic assessment tasks in learning the speaking skills. This test was administrated to both the experimental and control groups before and after applying the authentic assessment tasks -based strategy inside the experimental class. They were asked to answer the questions in 35 minutes .

Description of test items:

There were five dimensions including fourteen items. The total score of the test was 20 marks; each section of the test had four marks

In order to ensure the validity of the test, it was submitted to a jury including five members of EFL methodology staff, three supervisors and two expert teachers of teaching English. They indicated that the questions were appropriate and related to the objectives of the test.The reliability of the test was calculated using Cronbach's Alpha. It was calculated during the pre-testing stage. The test consists of five dimensions including fourteen items for speaking. The results indicated that the value of the total test of Cronbach`s Alpha for speaking test was 0.61. Based on this result, it can be said that the test was reliable. The current study took place in class 1/c at Fakous military Secondary School for Boys, Sharkia Governorate. The application started on Sunday $\mathbf{2 5}^{\text {th }}$ September 2016 and ended on Thursday $24^{\text {th }}$ November 2016. The researcher took the class for three periods a week, (40 minutes) on Sunday, one period (40 minutes) on Tuesday and one period (40 minutes) on Thursday. The total number of hours is $\mathbf{1 8}$ hours. A pre/post speaking test was administered to the groups. They were assessed using the suggested authentic assessment tasks.

\section{Proposed authentic assessment tasks:}

The purpose of the proposed learning materials wa to develop speaking learning of the EFL secondary school students adopting the authentic assessment approach. The Principles and components of the authentic assessment tasks process are:

1. Authentic assessment tasks ask students to demonstrate specific skills and apply the skills and knowledge they have mastered.

2. Authentic assessment tasks include the relationships between ideas, concepts and items. 
3. Authentic assessment tasks reflect student learning, achievement, motivation, and attitudes on instructionally-relevant classroom activities .

The types of authentic assessment tasks used:

1. Oral Interviews.

2. Story or text retelling.

3. Projects/ Exhibitions.

4. Role play

5. Writing samples to be read out.

6. Portfolios

These types were chosen as they are easy for the students to use and appropriate for the topics of the course and the strategy. They are appropriate in the Egyptian context.

\section{Intended Learning Outcomes:}

By the end of the eleven sessions in which authentic assessment tasks strategy was adopted, the participated in the treatment will be able to:

1. Describe people

2. Talk about the rights and the opportunities of women.

3. Start telling a story

4. talk about the difficulties that disabled people face.

3. Give advice.

4. Describe a friend

5. Give opinions talk about the countryside or the city.

6. Make polite requests and replies

7 . Discuss consequences, give reasons for and against argument

8. Discuss a questionnaire about new cities and talk about the advantages and disadvantages of new cities.

9. Read a text aloud.

10. Participate in a telephone interview.

11. Decide which syllable was stressed.

12. Respond to questions using information provided.

13. Show the difference or similarity in pronunciation.

14. Propose a solution.

\section{Methodology}

Based on the importance of authentic assessment tasks in teaching English language, the researcher adopted the authentic assessment tasks in teaching speaking skills as follows: 


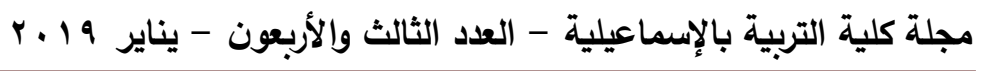

A. Pre teaching:

When introducing authentic assessment tasks to the students for the first time, it was best to base this on a topic that they have a sound knowledge of. To train his students to demonstrate and apply an authentic assessment task, the researcher illustrated to the students the different tasks related to authentic assessment that will be taught to them in the next sessions. Then, the pre-test was administrated to both the experimental and the control groups. The purpose of this test was to make sure that the groups to some extent are approximate in the performance level.

\section{B. During teaching}

The teacher's role, at this stage, was to circulate within the class and help learners formulate what they want to say, but not to intrude. The students participated in the task and the focus was on communicating meaning. Although the teacher worked as a facilitator most of the time at this stage, he helped students to cope with specific problems as they came up as follows:

a. He ensured that all students had a chance to participate in the tasks.

b. He provided clarification for the students so they won't lose the thread of what was going on.

c. He prevented digression or native language use.

c. He assigned one of the students for each peer/ group to observe his peers' performance and write some comments concerning problems in pronunciation, vocabulary, organization of discourse, grammar and appropriateness of response in a checklist provided by the teacher. Moreover, students' performance during performing the task was recorded by the teacher. In each lesson one or two pairs/ groups were recorded for subsequent analysis as not all the students could be recorded. In addition, the teacher walked around to gather common observations about each group to be handled later on with the whole class at post-teaching.

The output had to be expressed by the Students who had reached together and plan for the presentation of their results. During the planning period, the teacher was available to answer any questions concerning pronunciation, vocabulary and grammar. Moreover, the students were provided with many resources such as books and dictionaries. Students were also given special roles such as writer of notes, user of the dictionary, and presenter. Clarity, organization and accuracy were emphasized for a public presentation. 
C. Post teaching (Adapting authentic assessment tasks for the classroom):

The following activities helped the researcher to assess how far the students have understood the topic.

1. The researcher gave the students similar authentic assessment tasks and asked them to respond to them.

2. Students were asked to conduct self/peer evaluation of the tapes recorded during the task through using evaluation sheets that included the identified speaking skills. In addition, the observer assigned during the task was asked to give a general feedback about his group's performance.

3.The researcher helped students be constructive by mentioning good as well as bad things about their performance, and always make concrete suggestions for improvement.

\section{The Speaking Skills Final List}

\section{A. Fluency}

1.Speaking fluently without hesitation and undue pauses and adopting a natural rate of speech.

2.Produce fluent speech at different rates of delivery.

B. Pronunciation

3.Pronounce the distinctive sounds of a language clearly enough so that people can distinguish them. This includes making tonal distinctions.

4.Use stress and rhythmic patterns, and intonation patterns of the language clearly enough so that people can understand what is said.

C. Coherence and Cohesion

5.Expressing a range of functions to satisfy social and future needs. i.e. (Making suggestions, giving advice, agreeing and disagreeing with others' opinions, giving directions ...etc).

6.Presenting and seeking full autobiographical details.

D. Accuracy

7.Use vocabulary appropriately

8.Put words together in correct word order. 


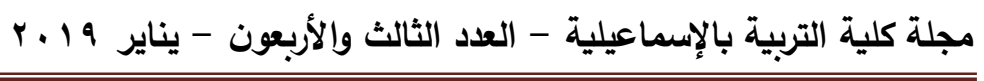

The speaking Pre/Post Test

(20 Marks)

Time:35 minutes

Answer the following questions:

A. Describing:

(Four

marks)

1.Choose a famous person who you know well. He/she can be alive or from history and talk as much as you can about him/her?(Two marks)

2.Describe this picture in as much detail as you can. You will have 30 seconds to prepare your response. Then you will have 2 minutes

to speak about the picture.(Two marks)

\section{B. Narration(Four marks)}

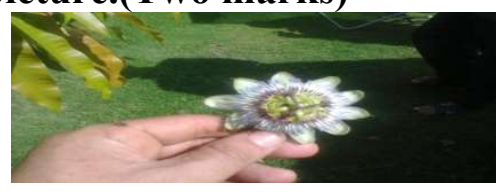

3.You have read "The cricket of the Hearth" tell the story from the point of view of the father then from the point of view of the daughter.(Two marks)

4. Put the following sentences in the correct order:(Two marks)

A It was called " the last waits"

$B$ the street was in total darkness.

$C$ because it was one he and Richard had learned at school.

D Peter looked outside.

E he recognized the tone.

$F$ and it seemed deserted.

$G$ he thought he heard someone whistling.

C. Functions(Four marks) one mark each

5. Give your younger brother some advice about the ways of learning vocabulary.

6. The interviewer asks you about your opinion about living in a city or the countryside. Tell him the advantages and disadvantages.

7. What do you think? Should women be allowed to run for presidency? Give reasons.

8. Suggest some ideas to solve the problems of traffic jams and pollution in your city.

D. Accuracy:(Four marks) one mark each

9. What about life after 50 years?

10. Imagine that a Canadian marketing firm is doing research in your country. You have agreed to participate in a telephone interview about television viewing 


$\begin{array}{llll}\text { 11. Say (S) for same or (D) for different: } \\ \text { 1. led } & \text { let } & \text { S } & \text { D } \\ \text { 2. bit } & \text { bit } & \text { S } & \text { D } \\ \text { 3. seat } & \text { set } & \text { S } & \text { D } \\ \text { 4. too } & \text { to } & \text { S } & \text { D }\end{array}$

12.Say the correct columns of the words. Look at the examples first $(\square \square=$ stress on second syllable $\square \square=$ stress on first syllable)

Autumn- advice -alone- annoy- attack- cartoon- climatecomplains - couple-crazy- Egypt- employ- exam- females- finalhabit- mirrorpolice rarely- repair- report-revise-useful- witness.

\begin{tabular}{|l|l|}
\hline Column 1 & Column 2 \\
\hline Autumn $\square \square$ & Advice $\square \square$ \\
\hline
\end{tabular}

E. Discourse competence:(Four marks)

13.write a paragraph about tourism in Egypt then read it out.(Two marks)

14. Your older brother is calling home from college for the first time. (Two marks)

a. Greet him.

b. Ask him if he likes his roommate.

c. Ask whether he likes his classes.

d. Ask about things he does on the week-end.

e. Say good-bye.

\section{Data analyses and Discussion}

The statistical analyses performed on the data gathered from pre and posttest as well as the results found by the researcher were tackled. The statistical package for the social science (SPSS) was used in analyzing all the data. The level of significance is set at 0.01. The results of this study were presented by relating them to the study hypotheses. The tables shown in this chapter include the marks of each part on the test .

The following statistical tools were used to measure the effect of the developed strategy: 
مجلة كلية التربية بالإسماعيلية - العدد الثالث والأربعون - يناير 9 ب. P

1. $t$ - Test

T- test was used in order to test the hypotheses of the study. This means to check the significant difference between the pre-post tool (the speaking test).

2. Effect Size $\left(\eta^{2}\right)$ :

Eta-Square $\left(\eta^{2}\right)$ was conducted to check the effect size of the developed learning material on the speaking skills and to test the hypotheses as well.

Table (4.8.): t-test of the Experimental group in the speaking pre and posttest overall speaking skills

\begin{tabular}{|c|l|l|l|l|l|l|l|l|l|}
\hline $\begin{array}{l}\text { Effect } \\
\text { Size } \\
\text { level }\end{array}$ & Sig. & Df & $\begin{array}{l}\text { t- } \\
\text { value }\end{array}$ & SD & M & N & Imp. & Group & Skill \\
\hline $\begin{array}{c}1.08 \\
\text { High }\end{array}$ & $\begin{array}{l}\text { 0.00 } \\
\text { Sig. }\end{array}$ & 58 & 33.4 & 3.7 & 14.1 & 30 & Pre & Experimental & $\begin{array}{l}\text { overall } \\
\text { speaking } \\
\text { skills }\end{array}$ \\
\hline
\end{tabular}

As shown in the table, the effect size of the authentic assessment strategy is high on learning speaking skills of the secondary schoolers. Such findings have proved that the authentic assessment strategy had a positive effect on learning speaking skills of the secondary schoolers . Thus, the hypotheses are verified.

This study is in line with Shehadeh's (2001) who proved the effect of using communicative tasks in developing speaking skills of English. This result also agrees with Nakatani (2005). who proved the effectiveness of the integrating both the cognitive approach strategies and task based instruction can foster students' speaking proficiency. These tasks can increase the students' motivation and positive attitudes towards learning to speak. Moreover, it increases students' ability to speak fluently and correctly. This is consistent with the results of other studies which proved the effectiveness of communicative tasks in developing speaking skills such as the studies of Nation (1991), Newton (1996), O'brein (1996), Bygate (1999), Dinapoli (2000), Myers (2000), and Shehadeh (2001). The authentic task enables them to understand and hence fosters their spoken performance. This is consistent with the results of other studies such as Slade \& Gardner (1993), Kubota (1995), House (1996), and Bejarano (1997).

To conclude, the results of the present study showed that the experimental and control groups had improvement on the post test of speaking skills compared to the pre-test. There was also an improvement on the speaking skills posttest of the experimental 
group compared to the control one. These significant differences may be due to exposing the experimental group to authentic assessment strategy which proved to be an effective strategy in learning speaking skills.

In addition, the results of the present study revealed significance at $(0.01)$ between the mean scores of the experimental group in developing speaking skills in favour of their posttest. This improvement is a result of using authentic assessment strategy in learning speaking skills these positive findings proved the effectiveness of the proposed strategy in developing first year secondary students' overall speaking performance and speaking subskills as well.

This study found out that using some authentic assessment tasks can enhance speaking skills learning of the secondary schoolers, where significant differences were found between the experimental and control group in the speaking test in favour of the experimental group. As well as, there were significant differences between the pre and post test of the experimental group in the speaking test in favour of the post test

\section{Conclusions}

In light of the findings of the current study, authentic assessment tasks we can conclude

It is an effective strategy in developing speaking skills in the secondary stage

1. There is evidence that exposing students to authentic texts via spoken language corpus driven materials, online or printed, helps to raise their consciousness and encourages them to draw insights especially about the lexical phrases and expressions used in authentic rather than artificial spoken discourse. It enables them to identify language features, which can enhance their pragmatic and discourse competence as well as their fluency.

2. It provides evidence for the effectiveness of using authentic tasks in developing first year secondary students' speaking skills. These tasks can increase their motivation and positive attitudes towards learning to speak. Moreover, it increases students' ability to speak fluently and correctly.

3. The key to sustained progress in speaking proficiency is balanced development in the different areas of language performance accuracy, fluency and complexity. This balance will lead to a situation in which progress in one area would be accompanied by 
مجلة كلية التربية بالإسماعيلية - العدد الثالث والأربعون - يناير 9 ا ـ ب

development in others. So complexity (acquiring new rules and restructuring the language system in terms of speaking skills) would be accompanied by the development of control over the newly acquired skills and the integration of these skills into fluent performance (Skehen, 1998).

4. To achieve this balance in terms of speaking both "analyzability and "accessibility" have to be developed. Analyzability helps the learner rely more on rule based system to produce language thus enables him to be more flexible, while accessibility is a memory based system which enables the learner to keep up with ongoing discourse using readymade lexical language.

5. Providing FL learners with explicit instruction before the task which does not only foster their understanding of spoken discourse characteristics, but it helps them to use these characteristics and their underlying skills in actual performance.

6. Helping students to plan before speaking and interacting orally proved to be effective in enhancing students' speaking performance in terms of all speaking skills.

7. Self/ peer-evaluation after performing tasks, enables students to direct and control their own learning as they pay more attention to their points of strength and weakness and hence motivate them to become more willing to self-correct and rebuild their underlying language system. This encourages students to be more involved in planning and organizing their future learning. 


\section{References}

Abu - Rahmah, M. (1997).English Instruction: Learning Materials for the EFL Course. Faculty of Education. Department of Curriculum \& Instruction. Suez Canal University.

Abu-Rahmah, M. I. (2001). 'Developing a task-based checklist for evaluating EFL student teachers' performance'. In ElNaggar (ed.)(2001), pp 117-127.

Ahmed, W. (2014).Developing Sixth Primary Students`English Listening Skills by Using Some Authentic Assessment Techniques.Unpublished M.A. Thesis, Faculty of Education, Suez Canal University.

Aitken, N. (2005). Literature Synopsis: Authentic Assessment. Albert Education. Retrieved from http://www.edc.gov.ab.ca

AL Khuli, S. (2000). The Effect of Using some Questioning Strategies in Teaching English on Developing the First Year Secondary School Students Speaking Skills. Unpublished M.A. Thesis, Faculty of Education, Ain Shams University.

Albert, A. (2004) . Creativity and Narrative Task Performance: An Exploratory Study". Language Learning, V. 54, n.2, Pp: 277381.

Bachman, L. (1990).Fundamental Considerations in Language Testing. Oxford, Oxford University Press.

Bachman, L. and Palmer, A. (1996).Language Testing in Practice: Designing and Developing Useful Language Tests. Oxford: Oxford University Press.

Bahrani, T. ,\&Sim, T. (2012). Audiovisual news, cartoons, and films as sources of authentic language input and language proficiency enhancement, The Turkish Online Journal of Educational Technology,11(4),56-64.Retrieved from www.tojdac.org/

Baker, D. (1989). Language Testing.A Critical Survey and Practical Guide. London: Edward Arnold.

Basturkmen, H. (2002). "Learner Observation of and Reflection on Spoken Discourse: An Approach for Teaching Academic Speaking". TESOL Journal, V.11, n.2, Pp: 26-30.

Beale, J. (2003). Assessing Interactive Oral Skills EFL Contexts in. http://www.jasonbeale.com/essaypages/assessment.html, accessed on 2ndJanuary, 2004.

Bejarano, Y.; and Others;(1997). "The Skilled Use of Interaction Strategies: Creating a Framework for Improved Small-Group 


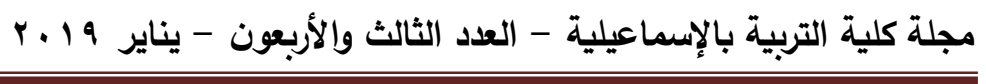

Communicative Interaction in the Language Classroom". System, V.25, n.2.Pp: 203-214.

Bransford, J. and Others; (1989) .The transition from theory to therapy: Test of two instructional methods. Applied Cognitive Psychology, 7, 139 - 153.

Brown, H. (2007). Teaching by Principles: An Interactive Approach to Language Pedagogy(2ndedition). New York: Longman, Inc.

Brown, R.(1987). "Group Work, Task Difference and Second Language Acquisition”.Applied Linguistics. V.11, n.1, Pp: 112.

Burns, A \& Joyce, H.(1997). Focus on Speaking. Sydney: National center for English Language Teaching and Research.

Bygate, M. (1999). "Quality of language and purpose of task: Patterns of learners' language on two oral communication tasks". Language Teaching Research V. 3, n. 3, Pp.185-214

Bygate, M. (1987).Speaking. Oxford: Oxford University Press.

Carter, R. \& McCarthy, M. (1997).Exploring Spoken English. Cambridge: Cambridge University Press

Dinapoli, R. (2000). Promoting Discourse with Task-Based Scenario Interaction. Paper presented at the International Conference on Language for Specific Purposes(Barcelona, Spain, September 7-9, 2000) (ERIC Document Reproduction Service No. ED: 454742).

Dornyei, Z. \&Thurrell, S. (1994). "Teaching Conversation Skills Intensively: Course Content and Rational". ELT Journal, V. 48, n. 1, Pp: 40- 49.

Doughty, C. (1991). "Second language Instruction Does Make a Difference: Evidence from an Empirical Study of Relativization". Studies in Second Language Acquisition, V.13,n.4, Pp: 431-469.243

Duff, P.(1986). "Another Look at Interlanguage Talk: Taking Tasks to Tasks” .In R. Day (Ed.)Talking to Learn. Conversation in Second Language Acquisition, (Pp: 147-181).Rowley, Mass: Newbury House.

El Touky, M.(1986). The Effect of a Program Designed for Developing Speaking Skills in English for First Year Secondary Students. Unpublished M.A. Thesis, Faculty of Education, Helwan University.

Ghanem, S.(1983). The Effect of Developing Verbal Interaction Pattern of Teaching English on the Speaking Skill of the 
Secondary Students. Unpublished PhD. Dissertation, Faculty of Education, Ain Shams University.

Gomm, H. \& Dallas, D. (1999).Hello! 6. Secondary English: Year 1. Student Book. Cairo: Egyptian International Publishing Company- Longman.

Gomm, H. \& Dallas, D. (1999).Hello! 6. Secondary English: Year 1. Teacher Guide. Cairo: Egyptian International Publishing Company- Longman.

Guillot, M. (2002). "Corpus-Based Work and Discourse Analysis in FL Pedagogy: A Reassessment". System, V. 30, n.1, Pp: 15-32

Halliday, M. (1975) .Learning How to Mean. London: Edward Arnold.

Harmer, J. (2001).The Practice of English Language Teaching. Edinburgh: Pearson Education limited.

Hughes, R. (2002). Teaching and Researching Speaking. Warlow: Longman.

Hussein, K.(1986). Classroom Processes and Developing Communicative Competence in English among Secondary School Students. Unpublished Ph.D. Dissertation.Faculty of Education, Zagazig University.

Kingen, S.(2000). Teaching Language Arts in Middle Schools. Connecting and Communicating. New Jersey: Lawrence Erlbaum Associates, Publishers.

Kubota, M. (1995)." Teachability of Conversational Implicature to Japanese EFL Learners". The Institute for Research in Language Teaching BulletinV.9, Pp: 35-67.

Luoma, S. (2004).Assessing Speaking. Cambridge: Cambridge University Press.

Lynch, T.(2001). "Seeing What They Meant: Transcribing as a Route to Noticing". ELT Journal. 55, n.2, Pp: 124-132.

McDonough, K. \& Mackey, A. (2000)."Communicative Tasks, Conversational Interaction and Linguistic Form: An Empirical study of Thai”. Foreign Language Annals. 33, n. 1, Pp: 82-91.

Ministry of Education (2016- 2017).Directives for General Secondary School Teachers of English. Cairo: Book Sector.

Myers, L.( 2000)." Task Interpretation and Task Effectiveness: A Vygotskian Analysis of a French L2 Classroom Task.". Texas Papers in Foreign Language Education, V.5,n.1, Pp: 9-21.

Nakatani, Y. (2005). "The Effects of Awareness-Raising Training on Oral 


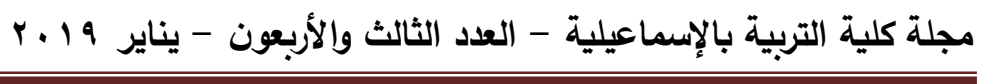

Communication Strategy Use". The Modern Language Journal, V. 89, n. 1,: 76 -91.

Nation, P. (1991). "Managing Group Discussion: Problem-Solving Tasks". Guidelines.V13, n.1, Pp: 1-10.

Nunan, D. (1999). Second language teaching and learning. Boston: Heinle\&Heinle Publishers.

Nunan, D.(1989). Designing Tasks for the Communicative Classroom. New York: Cambridge University Press.

Nunan, D.(2005). Task Based Language Teaching. Cambridge: Cambridge University Press.

O' Brein, N. (1996).Partnership In Learning: A Task Based Advanced Speaking Course. Paper presented in the Annual Meeting of Teachers of English to Speakers of Other Languages, Chicago, March, 1996. (ERIC Document Reproduction Service No. ED 395472).

O'Malley, J.M., \& Pierce, L.V. (1996).Authentic Assessment for English Language Learners: Practical approached for teachers. Redding, MA: Addison-Wesley.

Pearson, B. \& Lee, K. (1992)."Discourse Structure of Direction Giving: Effects of Native/ Nonnative Speaker Status and Gender". TESOL Quarterly, V. 26, n.1, Pp: 113- 126.

Rahimpour, M.(1997). "Task Complexity, Task Condition, and Variation in L2 Oral Discourse".Unpublished Ph.D Dissertation, University of Queensland, Australia.

Raja, J. (2001)."An Investigation of the Effectiveness of Teaching Pronunciation to Malaysian TESL Students". English Teaching Forum, V.39, n.3, Pp: 10-15.

Richards. J. (1990).The Language Teaching Matrix. Cambridge: Cambridge University Press.

Riggenbach, H. (1990). "Discourse Analysis and Spoken Language Instruction”. Annual Review of Applied Linguistics, V.2, n. 2, Pp: 152-163.

Riggenbach, H. (1998)." Evaluating Learner Interactional Skills. Conversation at the Micro Level".In R. Young \& A.He (Eds.). Talking and Testing. Discourse Approaches to the Assessment of Oral Proficiency,(Pp: 53-67). Amsterdam: John Benjamin's Publishing Company.

Rivers, W.(1981). Teaching Foreign Language Skills (2nd ed.). Chicago: University of Chicago Press.

Robinson, P. (1995). "Task Complexity, Task difficulty, and Task production: Exploring Interactions in a Componential Framework.”Applied Linguistics, V.22, n .1, Pp: 27-57. 
Robinson, P. (2000). "Task Complexity and Reasoning Demands: Effects on Dyadic (NNS)(NNS) Interaction, Fluency, Accuracy, Complexity and Incorporation of Input". Unpublished data, Aoyama Gakuin University, Tokyo.

Sayer, P. (2005)."An Intensive Approach to Building Conversational Skills".ELT Journal. V. 59, n.1,: 14- 22.

Shehadeh, A. (2001). "Self and Other-initiated Modified Output during Task-based Interaction". TESOL Quarterly. V.35, n. 3,: 433-57.

Skehan, P. (1998). "Task Based Instruction". Annual Review of Applied Linguistics,. V.18.n. 3, Pp: 268- 286.

Skehan, P. and Foster, P. (1997). "The Influence of Planning and Post Task Activities on Accuracy and Complexity in Task-Based Learning". Language Teaching Research,V.1, n.3, Pp: 16-33.

Slade, D. \& Gardner, R. (1993)." Teaching Casual Conversation: The Issue of Simplification".(ERIC Document Reproduction Service No. ED: 371579).

Slimani-Rolls, A. (2005). "Rethinking Task-based Language Learning: What We Can Learn from the Learners". Language Teaching Research. 9, n. 2, Pp. 195-218. 


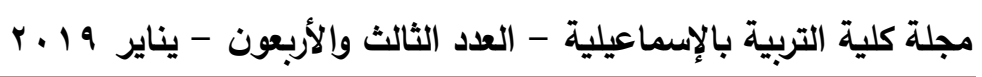
أنشطة قائمه علي التقويم الأصيل لتنمية مهارات التحدث باللغة الإنجليزية لاى

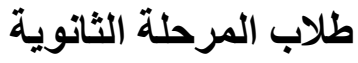

\author{
إعداد \\ فريد محمد كمال محمد عطية

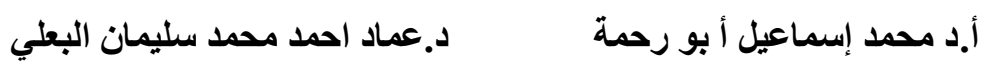

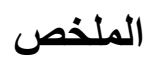

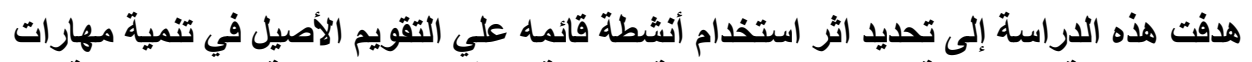

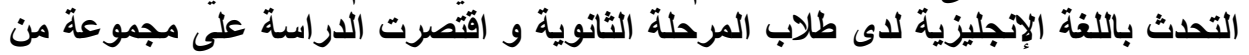

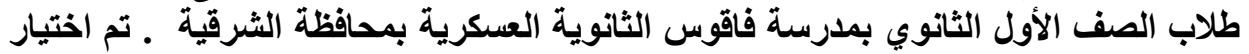

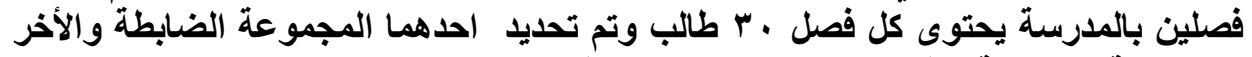

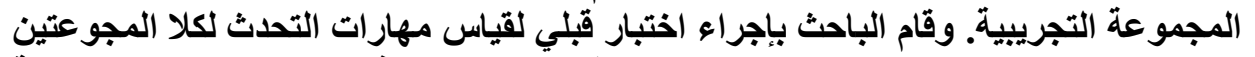

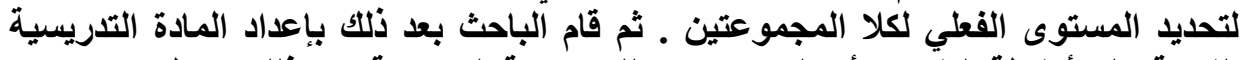

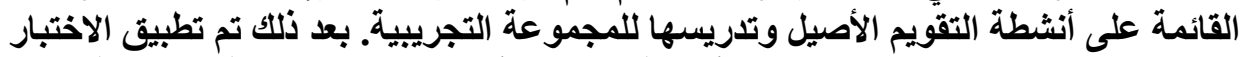

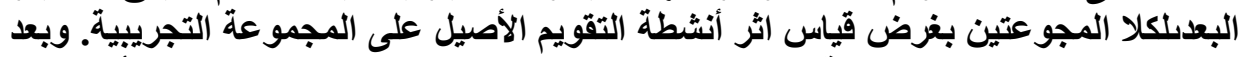

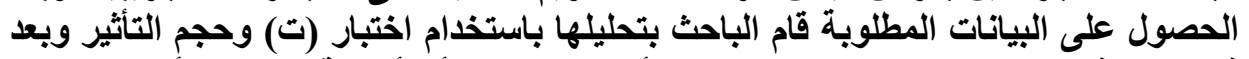

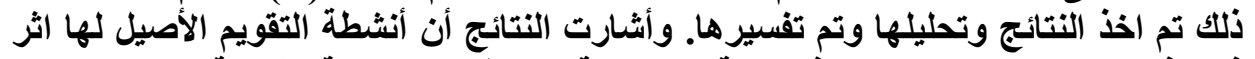

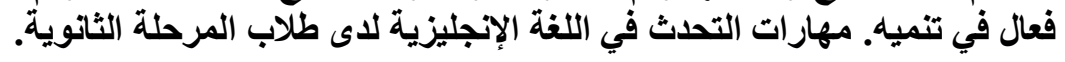
الكلمات ألمفتاحيه: التقويم الأصيلـ مهارات التحدث ـ المدارس الثانوية ـمصر. 


\title{
Authentic Assessment Tasks for Developing Secondary Schoolers' Speaking Skills
}

\author{
By
}

Farid Mohamed Kamal Mohamed Attia Prof. Mohammed Ismail Abu- Rahmah Dr. Emad Ahmed Mohamed Albaaly

\begin{abstract}
This study aimed at investigating the effect of using some authentic assessment tasks on developing secondary schoolers ${ }^{6}$ speaking skills. The design was the qusai experimental pre \& posttest. Two classes from Fakous Military Secondary School for Boys in Sharkia were randomly chosen . one was the experimental group and the second one was the control one. Each group consisted of thirty male students. The experimental group was taught using some authentic assessment tasks in learning speaking skills, whereas the control group was taught using the regular method. An achievement test was administrated to both groups. It consisted of fourteen questions . The test was administrated to the two groups before and after the treatment (using some authentic assessment tasks during October, November, and December, 2016). The obtained data were analyzed statistically through the use of Cronbach's Alpha, t- test and effect size. The results of the study revealed that the students taught by some authentic assessment tasks had better scores in the speaking skills test than those taught by the regular teaching. It can be concluded that the authentic assessment tasks had a significantly positive effect on speaking skills learning for this sample of the secondary school students.
\end{abstract}

Key Words: authentic assessment tasks; ELT; speaking skills; secondary schools, Egypt 